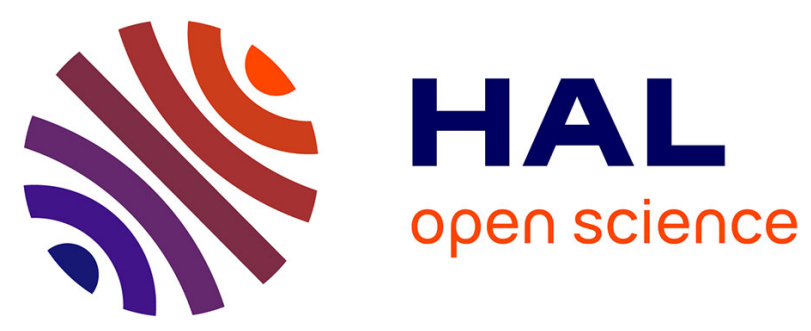

\title{
Applying a Living Lab Approach to Smart Grid Training Course Design
}

Alex Gabriel, Kévin Berger, Laurent Dupont, Valerie Rault, Mauricio

Camargo, Frédérique Mayer

\section{To cite this version:}

Alex Gabriel, Kévin Berger, Laurent Dupont, Valerie Rault, Mauricio Camargo, et al.. Applying a Living Lab Approach to Smart Grid Training Course Design. 2020 IEEE International Conference on Engineering, Technology and Innovation (ICE/ITMC), Cardiff University, Jun 2020, Cardiff, United Kingdom. pp.1-8, 10.1109/ICE/ITMC49519.2020.9198604 • hal-02884574

\section{HAL Id: hal-02884574 https://hal.science/hal-02884574}

Submitted on 30 Jun 2020

HAL is a multi-disciplinary open access archive for the deposit and dissemination of scientific research documents, whether they are published or not. The documents may come from teaching and research institutions in France or abroad, or from public or private research centers.
L'archive ouverte pluridisciplinaire HAL, est destinée au dépôt et à la diffusion de documents scientifiques de niveau recherche, publiés ou non, émanant des établissements d'enseignement et de recherche français ou étrangers, des laboratoires publics ou privés. 
Draft's authors: Gabriel A., Dupont L., Camargo M., Berger K., Rault V., Mayer F. ( 2020) Applying a Living Lab Approach to Smart Grid Training Course Design. 2020 IEEE International Conference on Engineering, Technology and Innovation (ICE/ITMC), June 15th-17th.

\section{Applying a Living Lab Approach to Smart Grid Training Course Design}

\author{
Alex Gabriel \\ Université de Lorraine, ERPI, F-54000 \\ Nancy, France \\ alex.gabriel@univ-lorraine.fr \\ Kévin Berger \\ Université de Lorraine, GREEN, F- \\ 54000 Nancy, France \\ kevin.berger@univ-lorraine.fr
}

\author{
Laurent Dupont \\ Université de Lorraine, ERPI, F-54000 \\ Nancy, France \\ 1.dupont@univ-lorraine.fr \\ Valérie Rault \\ Université de Lorraine, ERPI, F-54000 \\ Nancy, France \\ valerie.rault@univ-lorraine.fr
}

\author{
Mauricio Camargo \\ Université de Lorraine, ERPI, F-54000 \\ Nancy, France \\ mauricio.camargo@univ-lorraine.fr \\ Frédérique Mayer \\ Université de Lorraine, ERPI, F-54000 \\ Nancy, France \\ frederique.mayer@univ-lorraine.fr
}

\begin{abstract}
Humanity is facing environmental issues that require the whole way in which we produce, distribute, and consume energy to be challenged. One technical solution that is widely considered is the smart grid, meaning a decentralized and multi-scale smart energy system. For more than a decade, various pilot projects have been implemented successfully all over the European Union. If such pilots are to be scaled up into effective roll-outs, the electrical engineering workforce needs to be prepared, as do the public authorities, engineering researchers and broader public. They need quick awarenessraising and training in the benefits, drawbacks, opportunities and skills associated with smart grids. Due to the complex nature of the situation and the related challenges for society, designing this training requires an innovative and participative approach. This article proposes a case study on applying a living lab approach to the design of innovative online courses on smart grids.
\end{abstract}

Keywords: Smart Grid, Instructional Design, Pedagogy, Living Lab, Innovation

\section{INTRODUCTION}

The environmental issue is becoming inescapable. All human activity can be considered from the angle of sustainability and its environmental impact. Energy is certainly the most impactful lever for acting on sustainability, since it plays a part in all human activity, such as food production, preservation, preparation; transportation of people, foods or consumer goods; and production of consumer goods. Energy is the enabler of a successful society [1].

For decades, governments and governmental organizations have attempted to regulate human activities to limit their impact on the environment. One of the first examples was the Brundtland Commission to protect the ozone shield, in particular. Since the Kyoto Protocol came into force in 2005, the worldwide focus has been on greenhouse gas (GHG) emissions. The European Commission has set various objectives, with the first ones having a target date of 2020 [2]. By 2030, the Climate \& Energy Framework suggests cutting GHG emissions by at least 40\% from 1990 levels, reaching at least a $32 \%$ share of renewable energy and a $32.5 \%$ improvement in energy efficiency [3]. By 2050, the aim is to be climate-neutral, meaning a net-zero greenhouse gas emissions economy [4].

In order to achieve these objectives, one of the technical solutions backed by the European Union is the deployment of smart grids, in order to improve energy management, reduce environmental impacts and integrate emerging renewable energies. Another motivation for implementing smart grids is modernization of the infrastructure and the market promoted by the Energy Union since 2015 and observed annually [5]. Although some improvement was highlighted in the last report [5], accelerating the roll-out of the technology requires wider awareness among the actors involved in the implementation of smart technology.

One solution to raise awareness of smart grids and the energy transition among the actors concerned, such as users, public authorities, or industrialists, is training. Two perspectives can be considered to train and people and raise their awareness: initial education and continuing education. The current university curriculum should be updated to prepare future workers for job market needs. The difficulty lies in providing continuing education for the broader public, public authorities, engineers and the whole workforce in electrical engineering, as their needs are both varied and specific. Furthermore, smart grids are a complex topic that draws on various fields of knowledge.

In matters of innovation management, one way to deal with complex issues involving different stakeholders is a Living Lab (LL) approach [6]-[8]. However, while LL approaches can be linked to academic contexts [6], [9], [10], there is little literature on Living Lab approaches applied to pedagogical content creation.

Can the Living Lab approach be applied to the co-design of pedagogical content and training courses that provide a response to societal challenges in a complex system involving various stakeholders?

The second section of this article provides a theoretical basis to understand the complexity of smart grids, before presenting the LL approach as a way to innovate in the area of instructional design. Then, the third section presents the approach applied to design the course. A fourth section contains preliminary remarks on applying the LL approach in a pedagogical context. Finally, the fifth section discusses the suggested approach.

\section{LITERATURE REVIEW}

\section{A. The Smart Grid as a Complex System}

A power grid is the infrastructure that transports electricity from where it is generated to the consumer. It follows a topdown model where electricity is generated in bulk centralized units and passes through transformers and transmission substations before being provided to the consumer through distribution substations and power distribution lines [11]. The responsibilities of power utilities consist in providing enough electricity to satisfy demand, while ensuring power supply 
quality and reliability. A failure in managing this aspect, due notably to ageing infrastructure, a slow response, increasing energy demand or the increasing diversity of energy sources, could lead to a blackout - a temporary interruption of electricity supply to a geographical area.

One of the solutions to optimize power quality, reliability and environmental impact is demand-side management [12]. This is the planning, implementation, and monitoring of those utility activities designed to influence customers' use of electricity in ways that will produce desired changes in the utility's load shape, i.e. changes in the time pattern and magnitude of a utility's load [12]. The main concept of load management is to shift load from high-demand periods to periods with lower demand [13]. Achieving this demand-side management requires communicating infrastructure which is the core of the smart grid concept [11]. The smart transition is transforming power grids from a passive to an active infrastructure. A smart grid is an active electricity network that ensures efficient, sustainable electricity supply, with lower losses and cost and greater reliability and security through two-way flow of real-time data and bi-directional energy transfer [1], [14]. The smart grid is envisioned as a large-scale cyber-physical system encompassing advanced power, communications, control, and computing technologies [15]. It is a power network composed of intelligent nodes that can operate, communicate, and interact, autonomously, in order to deliver power and electricity efficiently to their consumers [15]. The main characteristics of smart grids [16], [17] are the following:

- Flexible: fulfilling customers' needs while responding to the changes and challenges ahead;

- Accessible: granting connection access to all network users, particularly for renewable power sources and high-efficiency local distributed generation with zero or low-carbon emissions;

- Reliable and resilient: assuring and improving security and quality of supply, consistent with the demands of the digital age, with resilience to hazards and uncertainties;

- Economic: providing the best value through innovation, efficient energy management, and "level playing field" competition and regulation.

In addition to these characteristics, smart grid implementations are complex systems [1] as they imply various types of actors, needs and technologies [18]. Smart grids can also be considered through the construction industry sector, as in Tronchin and colleagues [18], but buildings are nodes in the energy infrastructure of cities. Effectively, a distributed energy system replaces or complements largescale and centralized generation plants, with smaller units located close to consumers and multiplying sources of energy [19].

From a sustainability perspective, smart grids are crucial subsystems of a larger system named Global Power and Energy Internet (GPEI) [17] that bypasses conventional linear energy supply. GPEI extends the smart grid concept beyond electricity and toward "highly interconnected and coupled energy systems [that] bring significant optimization in energy production, energy transportation, energy distribution, energy consumption, and energy utilization as well as energy efficiency improvement, implementation of energy-saving and emission reduction policies" [17]. It is based on effective integration, highly synergetic and active interaction and realizes interconnection and interoperability [17]. GPEI explicitly defines seven scale levels for the power and energy system: intercontinental, continental, transnational/regional, national, urban, community, and user (Fig. 1). Furthermore, crosswise to these scales, sources of energy such as electricity, gas, heat and transport are considered as tightly coupled and considered through the physical energy network and the informational network [17]. Named either Energy Internet [20] or Global Power and Energy Internet [17], both represent a network with high complexity where information and energy are integrated in depth and share equal access to multiple types of energy resources through a variety of energy transmission media [20]. This represents a novel energy interaction mode based on a cyber-physical-economy-energy model [20]. In other words, each layer of GPEI is a system, but it is also a sub-system of the social, economic, legal and ecological environment, as well as a technical sub-system of another layer (Fig. 1). In this system, each layer is interlinked with another. With this systemic representation, smart grids can be described as electrical infrastructures that are specific to each layer and coupled with other layer infrastructure thanks to the information system.

Smart grids are complex systems that involve various kinds of expertise for optimal management and operation. Professionals in the sector must therefore acquire multidisciplinary knowledge and managers must coordinate multidisciplinary teams. Multidisciplinary teaching should be dispensed by academics and adapted to the profile of the learner. How can we design the content that is best suited to a learner's needs?

\section{B. Living Lab Applied to Instructional Design}

A Living Lab is a design research methodology that has developed strongly since the mid-2000s [7] and is aimed at cocreating innovation through the involvement of aware users in a real-life setting [21]. LL is an ecosystem approach in which end users and other stakeholders are involved in the development of an innovation, in real-life environments, following iterative processes and applying multi-method, user-centric innovation research with a strong focus on user empowerment and real-world experimentation [8]. In terms of use cases, LL methodology can be applied to exploiting the potentialities of existing technologies or to exploring the opportunities provided by new technologies [21]. Concerning the participants in the workshop, they can be pre-selected people to address a defined knowledge domain, or preference may be given to leveraging the serendipity value of "unknown" participants [21]. It is an approach that is

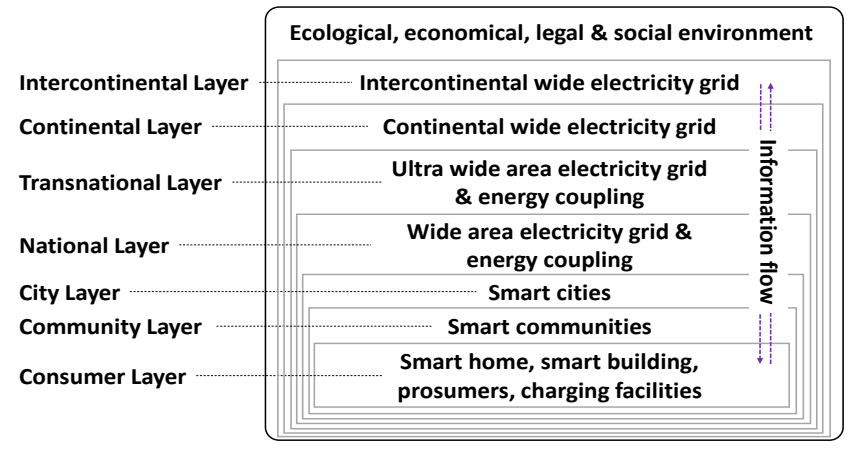

Fig. 1. Interlinked infrastructures from GPEI layers thanks to information flow 


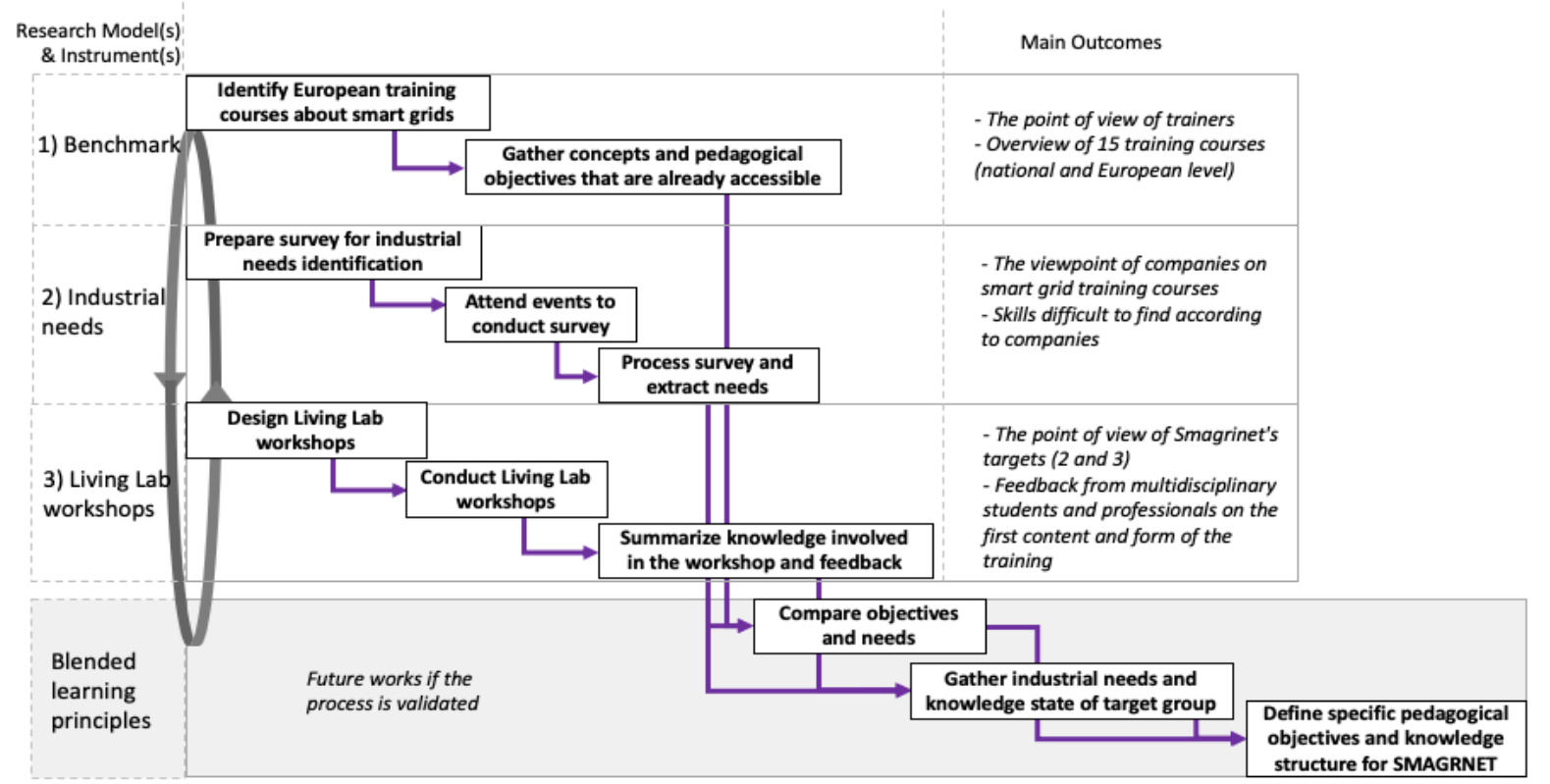

Fig. 2. Symbolic representation of the three lines of work, their composition and how they feed into the SMAGRINET blended learning approach

particularly well adapted to complex situations that need the empowerment of stakeholders. In addition, the LL approach can be used and adapted to different levels of analysis, from the system to the different stages of a project [22], [23]. As described on its smart specialization platform, the European Commission considers Living Labs to be a tool to involve stakeholders in the design process in order to promote economic and societal development [24].

From the instructional design perspective, the success of any learning environment is determined by the degree to which there is adequate alignment between eight critical factors: goals, content, instructional design, learner tasks, instructor roles, student roles, technological affordances, and assessment [25]. As the topic of smart grids is multi-scale, multi-expertise and multi-stakeholders, it seems relevant to adopt an LL approach to design training courses. In order to create a shared representation and understanding of this topic and create teaching modalities that satisfy everyone, all the stakeholders should be involved in the process, whether academics, companies or citizens. All of them provide their knowledge and skills according to their background, objectives, motivation and resources. This situation can be seen as a university-industry-government-civil society relationship, aka quadruple helix innovation model [26], that is commonly supported by Living lab approaches [8]. Although the LL approach has already been applied to cases such as the smart city [27], smart building [8], smart metering [28], consumer energy market [23] or Home Energy Management Systems [29], there is very little literature presenting the implementation of an LL approach to instructional design on to these topics. Based on our current state of knowledge, the closest LL experiment to this one is certainly that of the University Living Lab initiative from the University of Manchester [30].

The ambition of the LL approach applied to instructional design on the topic of smart grids is to co-design the training methods, contents and roles through iterative sessions with academics, students, companies, policymakers and citizens. The next section will present in detail how this approach was applied.

\section{METHODS}

The experiment was part of the SMAGRINET European project that aims to accelerate the spread of smart grid technologies throughout Europe via the creation of initial education lectures and continuous education programs, both specialized in smart grids. The continuous education programs target three types of audience: the electrical engineering workforce (target 1), engineering researchers (target 2), and the broader public, including policymakers and public authorities (target 3). Due to the type of target, the assumption is that blended learning principles should be adopted for the continuous education component.

In order to co-design the continuing education material with the various stakeholders, an action research method was adopted, meaning that the subject was explored interactively and iteratively according to the activities implemented. These activities were structured into three complementary and parallel lines of work, also illustrated in Fig. 2:

- a literature review \& benchmark to collect the trainers' points of view,

- an industrial needs survey based on a semi-directed interview to understand the needs and expectations of industrial stakeholders,

- LL workshops supported by the Lorraine Fab Living Labß (LF2L) platform, Nancy, France [31] to involve the trainees, in particular neophyte citizens and local authority professionals on the issue of smart grids.

These three lines of work were carried out in parallel by the same team of trainers in order to allow rapid iterations in their design work.

The benchmark line of work aimed to create a common understanding of the field among the team. It was even more important as each had a specific perspective according to their respective expertise and none had an overall vision of smart grids. This benchmark consisted in identifying training courses concerning smart grids and listing their content. It also 


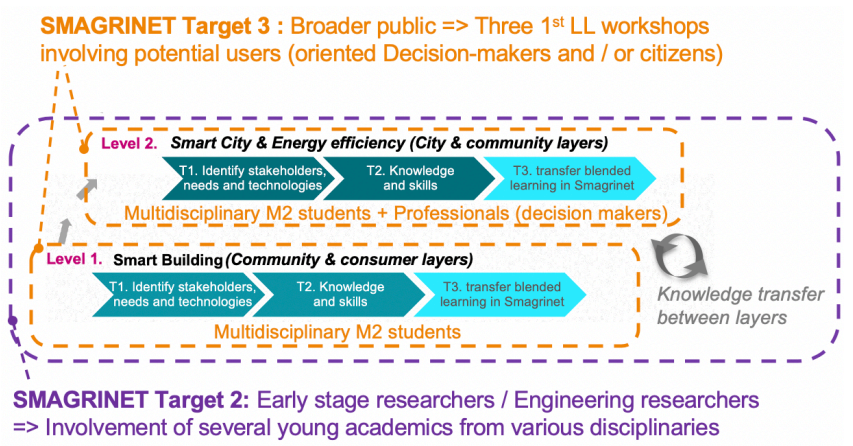

Fig. 3. Targeted profiles according to the 3 Living Lab design workshops for 2 GPEI levels

allowed us to obtain the current point of view of trainers. This review led us to identify 15 courses or training activities held in English or in French. These courses could be classified either as initial training or continuing education and could be attended either in the classroom or online (Table I).

The second line of work aimed to identify industrial topics, skills needs and training methods. The motivation was to collect information in order to compare it with the benchmark in a subsequent activity. The most significant information gathering took place during European Utility Week 2019, when a survey was carried out among 31 European companies. It was the easiest way to involve people close to the electrical engineering workforce (target 1).

The third line of work consisted in holding Living Lab workshops (Fig. 3). The objective of these workshops was to involve stakeholders and people representing future target groups in co-designing the training. To do so, the broader public (target 3) was represented by multidisciplinary Master's 2 students from different fields of knowledge and professionals in lifelong learning with various backgrounds and advising policy decision-makers. The engineering researcher (target 2) was represented by academics - $\mathrm{PhD}$ students and young researchers with 2 to 10 years of experience. These workshops followed a method that has been validated for territorial projects [32], although it was adapted slightly to have a twofold perspective during these workshops:

- P1 - Solving urban planning problems using smart grid principles and technologies. This was mandatory as the LL principle requires a real-life problem.

- P2 - Having a reflexive approach in which knowledge is required to understand and address the challenges related to smart grids.

TABLE I. CLASSIFICATION OF TRAINING COURSES REVIEWED TO IDENTIFY CONCEPTS TO SMART GRID

\begin{tabular}{|l|l|l|}
\cline { 2 - 3 } \multicolumn{1}{c|}{} & Initial training & \multicolumn{1}{c|}{ Continuing education } \\
\hline \multirow{4}{*}{$\begin{array}{l}\text { Classroom } \\
\text { based }\end{array}$} & ENSE $^{3}$ & CEA-INSTN \\
& CNAM & S2E2 (3 trainings) \\
& Master OSE & $\begin{array}{l}\text { SMART USE } \\
\text { MBA Smart Energy - Institut Léonard } \\
\text { de Vinci }\end{array}$ \\
\hline & & Genoble Ecole de Management \\
& & (FutureLearn) \\
Online & & Université Grenoble Alpes (FUN) \\
& & EIT InnoEnergy (FutureLearn) (3 \\
& & trainings) \\
& & DelftX (EdX) \\
\hline
\end{tabular}

As highlighted by the GPEI model, smart grids can be understood through different layers of complexity. In order to both present and limit the complexity of smart grids, the topics of the LL workshops were defined to combine two levels of complexity, as shown in Table II. Three workshops were organized to cover these topics. From the instructional design perspective (P2), each workshop was structured in 3 stages:

- T1 - Identify stakeholders, needs and technology

- T2 - Designate / check knowledge, skills and learning practices

- T3 - Transfer learnings from the workshop to pedagogical content for the blended learning programs.

From the operational perspective, each workshop was held over several days, with plenary sessions led by experts in the morning and autonomous sessions in the afternoon to work on solving the problem defined at the beginning of the workshop. The objective of the plenary sessions was to present concepts and tools that would be useful for solving the problem. The end of the workshops consisted in presenting solutions to stakeholders, professionals or representatives of the city, according to the problem solved. After the workshops, the materials that were produced were collected and participants were asked to answer a survey. The qualitative survey made the participants think reflexively about how the case-based workshops adopting the LL approach had helped them understand smart grid concepts better at Smart City or Smart Building levels (T3 in Fig. 3). The assumptions were that after taking part in the problem-solving, the participants would be able to identify which knowledge and skills had been useful to reach the solution. The workshop objectives, duration, and profiles of participants are summarized in Table IV. In order to support the "Smart grids in territories" and "Smart grid and territories policy" workshops, qualitative data was used from a citizens' workshop to design an eco-neighborhood in Nancy, France [32]. This workshop was dedicated to energy efficiency and involved 185 participants: users, policymakers, technicians, companies, researchers and students, etc. in the first semester of 2014 [33]. Concerning the "Smart buildings \& microgrids" workshop, the objective was to convert the building where the workshop was taking place into a smart building. The intention was to allow exchanges between the participants and academics that use this building, as they would all be impacted by the suggested solutions.

The next section presents the data and outcomes collected during the implementation of this method.

\section{FINDINGS}

\section{A. Benchmark}

First of all, the benchmark shows that there is already a broad spectrum of training courses. Analysis of the course

TABLE II. THE THREE LAYERS OF COMPLEXITY INTRODUCED BY THE TOPICS OF LIVING LAB WORKSHOPS BASED ON THE GPEI MODEL

\begin{tabular}{|l|c|c|c|}
\hline \multicolumn{2}{|c|}{ Topics } & \multicolumn{3}{|c|}{ GPEI model layers } \\
\cline { 2 - 4 } & Consumer & Community & City \\
\hline $\begin{array}{l}\text { Smart grids in } \\
\text { territories }\end{array}$ & & $\mathrm{X}$ & $\mathrm{X}$ \\
\hline $\begin{array}{l}\text { Smart buildings \& } \\
\text { microgrids }\end{array}$ & $\mathrm{X}$ & $\mathrm{X}$ & \\
\hline $\begin{array}{l}\text { Smart grid and } \\
\text { territories policy }\end{array}$ & & $\mathrm{X}$ & $\mathrm{X}$ \\
\hline
\end{tabular}


TABLE III. CHARACTERISTICS OF ORGANIZED LIVING LAB WORKSHOPS

\begin{tabular}{|c|c|c|c|c|}
\hline Workshop & Objectives & Duration & Number of participants \& profile & $\begin{array}{l}\text { SMAGRINET } \\
\text { Target }\end{array}$ \\
\hline $\begin{array}{l}\text { Smart grids } \\
\text { in territories }\end{array}$ & $\begin{array}{l}\text { Co-design an eco-district of the city, } \\
\text { including energy efficiency and } \\
\text { potential integration of smart grids }\end{array}$ & $\begin{array}{l}5 \text { days in } \\
\text { Nov. } 2019\end{array}$ & $\begin{array}{l}19 \text { Master's } 2 \text { students specialized in territories } \\
\text { management } \\
5 \text { Academics: urban innovation (1), decision-making } \\
\text { process (2), energy mix approach (2) }\end{array}$ & $\begin{array}{l}\text { Target } 3 \\
\text { Target } 2\end{array}$ \\
\hline $\begin{array}{l}\text { Smart } \\
\text { buildings \& } \\
\text { microgrids }\end{array}$ & $\begin{array}{l}\text { Design and define the architecture } \\
\text { of a smart building as part of a smart } \\
\text { grid, considering usage }\end{array}$ & $\begin{array}{l}5 \text { days in } \\
\text { Dec. } 2019 \\
5 \text { days in } \\
\text { Feb. } 2020 \\
\end{array}$ & $\begin{array}{l}23 \text { Master's } 2 \text { students specialized in information system } \\
\text { design and architecture } \\
6 \text { Academics: electrical engineering } \quad \text { (2), systems } \\
\text { engineering (3), urban innovation (1) }\end{array}$ & $\begin{array}{l}\text { Target } 3 \\
\text { Target } 2\end{array}$ \\
\hline $\begin{array}{l}\text { Smart grid } \\
\text { and } \\
\text { territories } \\
\text { policy }\end{array}$ & $\begin{array}{l}\text { Co-design an eco-district of the city, } \\
\text { including energy efficiency and } \\
\text { potential integration of smart grids }\end{array}$ & $\begin{array}{l}4 \text { days in } \\
\text { Jan. } 2020\end{array}$ & $\begin{array}{l}12 \text { Professionals from the French territorial administration } \\
\text { (local and national levels) in lifelong learning programmes } \\
5 \text { Academics: urban innovation (2), decision-making } \\
\text { process (1), energy mix approach (2) }\end{array}$ & $\begin{array}{l}\text { Target } 3 \\
\text { Target } 2\end{array}$ \\
\hline
\end{tabular}

curriculum or pedagogical content enabled the concepts associated with smart grids to be identified. The concepts identified were indexed, mapped and gathered. Table III

presents an abstract of the concepts that were identified as related to smart grids. This mapping is essential to define both educational objectives and course content. The second benefit of this is its communication potential. The mind map version can be a tool for communication with industrialists to clarify the knowledge and skills required for somebody working on the subject of smart grids. Although the content that was identified was rich and interesting, what was missing in all these courses was the description of a comprehensible "big picture". In other words, a more systemic approach is still needed, i.e. The different actors must be helped to make the link between technologies, knowledge and layers of intervention. Furthermore, these courses do not target the non-technical audience, such as users and decision-makers, and addressing these targets would constitute an opportunity.

\section{B. Industrial Needs Survey}

Meeting industrialists made it possible to identify the skills they declare as being required to work on smart grids (Fig. 4), and the skills companies are having difficulties finding (Fig. 5).

Most respondents declared that they did not have formal training processes, except for large companies. Small and medium-sized companies rely on mentoring and knowledge transfer, with the seniors teaching the juniors the technical and practical aspects, while the juniors teach the seniors about IT aspects, such data analysis or AI. Large companies train their workforce internally.

By matching this information with the concept mapping from the benchmark, we were able to identify new concepts and topics. Fig. 5 underlines the key topics for companies. The inclusion of the local territory and citizens would appear not to feature among their needs, however, despite previous research having shown that smart grids are above all sociotechnical systems that must include users as early as possible in their design and development [28]. More predictably than in the case of the benchmark, the needs survey among industrialists shows that internal training courses are dedicated to their electrical engineering workforce. Big compagnies do not target users, policymakers or researchers. Furthermore, unlike large companies, SMEs do not benefit from the same internal resources for training their workforce. The perspective of continuous education programs is therefore to target the electrical engineering workforce in SME. There are thus considerable opportunities for training the broader public and engineering researchers.
TABLE IV. CONCEPTS AT THE 2ND LEVEL OF THE MAPPING

\begin{tabular}{|c|c|}
\hline $\begin{array}{l}\text { Modules (1 } \\
\text { level) } \\
\end{array}$ & Concepts $\left(2^{\text {nd }}\right.$ level $)$ \\
\hline $\begin{array}{l}\text { Challenges \& } \\
\text { contexts }\end{array}$ & $\begin{array}{l}\text { embedded electricity } \\
\text { balance management } \\
\text { roles in the power supply chain } \\
\text { smart values (flexibility, reliability, accessibility, } \\
\text { economy) } \\
\text { introduction of renewable energy } \\
\mathrm{CO}^{2} \text { emission reduction }\end{array}$ \\
\hline $\begin{array}{l}\text { Electrical } \\
\text { network } \\
\text { elements }\end{array}$ & $\begin{array}{l}\text { distribution } \\
\text { transmission } \\
\text { cross-border networks } \\
\text { electricity storage } \\
\text { substations } \\
\text { power transformation electronics } \\
\text { power sources } \\
\text { control } \\
\text { loads } \\
\text { end energy }\end{array}$ \\
\hline $\begin{array}{l}\text { Information } \\
\text { system } \\
\text { dedicated to } \\
\text { energy }\end{array}$ & $\begin{array}{l}\text { cybersecurity } \\
\text { modeling skills } \\
\text { monitoring and control } \\
\text { automation - SCADA } \\
\text { network / communication }\end{array}$ \\
\hline $\begin{array}{l}\text { Management } \\
\text { and decision- } \\
\text { making } \\
\text { system }\end{array}$ & $\begin{array}{l}\text { active network management } \\
\text { data usage and management - AI } \\
\text { multicriteria decision analysis } \\
\text { price / load / production forcasting } \\
\text { data analytics } \\
\text { demand-side management }\end{array}$ \\
\hline $\begin{array}{l}\text { Energy policy } \\
\text { and } \\
\text { economics }\end{array}$ & $\begin{array}{l}\text { political, legal and normative dimensions } \\
\text { data policy - RGPD } \\
\text { business model } \\
\text { electricity market \& actors } \\
\text { market deregulation }\end{array}$ \\
\hline
\end{tabular}

\section{Living Lab Workshop}

The first LL results come from the answers of participants in the two workshops focusing on "smart grids in territories" and "smart grid and territories policy". Qualitative data was provided by 18 multidisciplinary second-year Master's students and 7 professionals in lifelong learning. They answered the same survey concerning the content and form of the LL workshop. In this first Living Lab experiment, the questionnaire was deliberately made up of open-ended questions distributed at the end of the workshop. Participants had up to 3 days to complete it. The objective was to collect the widest possible feedback to cover the heuristic saturation of the panel.

Participants underlined three positive aspects of the LL workshops: 1) the content was in line with the complexity of reality: "A global approach: technological, societal and 


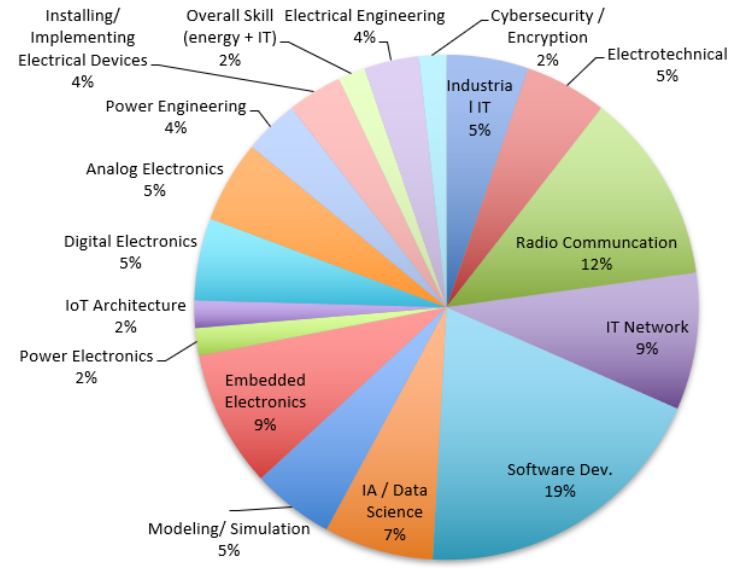

Fig. 4. Skills declared as required by companies for working on smart grid

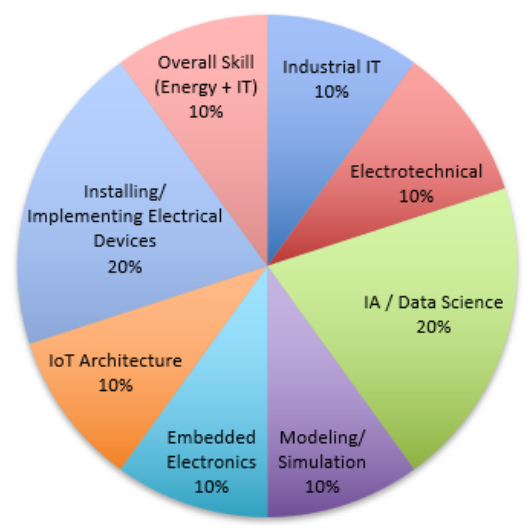

Fig. 5. Skills difficult to encounter according to declaration of companies

economic", "An overall vision of a subject by integrating different parts"; 2) new learning: "Be aware of a topical issue that raises awareness", "Understand that solutions need to be adapted to the territories and that stakeholders may have diverging visions", "Knowing how to deal with the diversity of actors and technologies"; the pedagogical form: "The time for interaction with the experts and their accessible message to enrich the debate, their availability and their engagement", "The autonomy offered in the work", "The possibility of adopting different roles and situations, with a real case studied", "Step-by-step progress with the use of various tools".

Nevertheless, they did not appreciate some aspects and had some questions. They explained in the survey that the workshop was based on a concrete case that had already arisen, and that it was not a real situation to be faced, which reduced the motivation and the challenge. In particular, some participants suggested increasing the implication of stakeholders. Other participants would have liked more background material (references, online courses, etc.). There was probably too much information to absorb in 4 or 5 days according to the feedback from three people. They imagined themselves in the professional situation and questioned whether the tools were transferable to real situations, without an expert to accompany the practitioners and without having as much time as that allowed by the pedagogical process. Some participants even wanted to go further on the conditions to be created, e.g. use a comparative approach, present the limits of the technologies, their impacts, in order to adopt a more critical stance on the proposed technologies to make choices that offer better energy efficiency and, more generally, exemplary environmental performance. Finally, one of them imagined a representation of the short-, mediumand long-term consequences of the decisions taken. In other words, the suggestions highlighted a need to reinforce the temporal perspective in the workshop.

Finally, if the content of these workshops were to be offered by distance learning, different ideas were proposed: "Organize a visit to a power plant or a photovoltaic panel facility to better appreciate the technologies and the framework of the solutions", "Don't focus only on energy and smart grids but offer a multi-dimensional challenge", "Using social networks and give the opportunity to read theses and papers", "Have access to summary sheets with technical data", "Use virtual or immersive devices to reinforce the simulations on the case under study". However, although the participants did imagine the use of MOOCs, videos, teleconferencing, interactive exhibitions, etc. they would also like these technologies to be associated with workshops bringing together experts and local stakeholders.

\section{CONCLUSION}

\section{A. Limitations}

This article presents a case study about the usage of an LL approach in the context of a continuous education program for people from various backgrounds on the complex subject of smart grids. The complementary results provided by benchmarking, a survey of industrialists' needs and LL workshops are insightful in terms of creativity and remarks. However, the quality of the feedback was largely dependent on how the workshop was organized. In this case study, there were no representatives of the electrical engineering workforce (target 1) involved in the LL workshop. Furthermore, the feedback mainly concerned the problemsolving perspective (P1) of the approach. To assess the relevance of the approach to the instructional design issue properly, continuous education programs must be created, implemented and evaluated. This is actually the early stage of designing these programs. Concerning the results and feedback, they were mainly qualitative and in French, which would make the approach difficult to compare from one context to another, in particular for a European project. Nevertheless, smart grid technologies and protocols are shared at European level and the SMAGRINET project is still underway.

\section{B. Concluding Remarks}

By mixing the state of the art, benchmarking, needs surveys and LL workshops, this study presents an original approach to the implementation of LL methods for instructional design. Solving a problem collaboratively and thinking about the knowledge and skills required is at least one way to raise awareness among students, teachers, researchers and industrialists of environmental challenges (greenhouse gas emissions) and their complex relationship with energy. Organizing workshops with participants with different profiles is interesting to identify the relevant way to improve skills and knowledge about Smart Grids. Although no representatives of the electrical engineering target group were present during workshop, the needs survey enabled them to be involved in the instructional design process. In a context of technological shifts, the suggested approach can contribute to changing educational practices in order to handle complex 
TABLE V. MODULES AND CORRESPONDING EDUCATIONAL OBJECTIVES FOR THE CONTINUOUS TRAININGS

\begin{tabular}{|c|c|c|}
\hline Modules & $\begin{array}{l}\text { Engineering } \\
\text { researcher }\end{array}$ & Broader public \\
\hline $\begin{array}{l}\text { Challenges } \\
\text { \& contexts }\end{array}$ & $\begin{array}{l}\text { Explain impacts of } \\
\text { smart grids at different } \\
\text { scales (home, building, } \\
\text { city, territory) } \\
\text { Explain the role of } \\
\text { smart grids in energy } \\
\text { transitions and the } \\
\text { changing roles of actors } \\
\text { in the value chain }\end{array}$ & $\begin{array}{l}\text { Define impacts of smart } \\
\text { grids at different scales } \\
\text { (home, building, city, } \\
\text { territory) } \\
\text { Define the role of smart } \\
\text { grids in energy transitions } \\
\text { and the changing roles of } \\
\text { actors in the value chain }\end{array}$ \\
\hline $\begin{array}{l}\text { Electrical } \\
\text { network } \\
\text { elements }\end{array}$ & $\begin{array}{l}\text { Identify and understand } \\
\text { the functioning of } \\
\text { technical elements that } \\
\text { are part of the smart } \\
\text { grid in order to } \\
\text { contribute to their } \\
\text { specific research fields. } \\
\text { Identify and understand } \\
\text { the main functioning } \\
\text { modes of electric grids } \\
\text { (transmission, } \\
\text { distribution) and } \\
\text { interconnection } \\
\text { constraints }\end{array}$ & $\begin{array}{l}\text { Identify main functioning } \\
\text { modes of electric grids } \\
\text { (transmission, distribution) } \\
\text { and interconnection } \\
\text { constraints. }\end{array}$ \\
\hline $\begin{array}{l}\text { Information } \\
\text { system } \\
\text { dedicated to } \\
\text { energy }\end{array}$ & $\begin{array}{l}\text { Explain digital } \\
\text { components that } \\
\text { contribute to smart } \\
\text { grids. } \\
\text { Explain the nature and } \\
\text { the path of data } \\
\text { involved in smart grids. }\end{array}$ & $\begin{array}{l}\text { Identify digital components } \\
\text { that contribute to smart } \\
\text { grids. } \\
\text { Identify the nature and the } \\
\text { path of data involved in } \\
\text { smart grids. }\end{array}$ \\
\hline $\begin{array}{l}\text { Management } \\
\text { and } \\
\text { decision- } \\
\text { making } \\
\text { system }\end{array}$ & $\begin{array}{l}\text { Explain mechanisms } \\
\text { and levers of action for } \\
\text { operation optimization } \\
\text { and network efficiency }\end{array}$ & $\begin{array}{l}\text { List mechanisms and role } \\
\text { of digital technologies in } \\
\text { operation optimization and } \\
\text { network efficiency. } \\
\text { List the usage of data in } \\
\text { optimizing network } \\
\text { efficiency }\end{array}$ \\
\hline $\begin{array}{l}\text { Energy } \\
\text { policy and } \\
\text { economics }\end{array}$ & $\begin{array}{l}\text { Explain the } \\
\text { development plan for } \\
\text { smart grids in regards } \\
\text { to pricing policy and } \\
\text { return on investment }\end{array}$ & $\begin{array}{l}\text { Identify main trends of EU } \\
\text { policy that influence smart } \\
\text { grid territories } \\
\text { Identify a development } \\
\text { plan for smart grids }\end{array}$ \\
\hline
\end{tabular}

topics with systemic impacts and multiple layers and stakeholders.

Finally, according to these first experiments and outcomes, it was possible to define contents and educational objectives for two of the three audiences targeted by the continuous training programs. Table $\mathrm{V}$ presents modules and corresponding educational objectives for the broader public and engineering researchers. These modules will be dispensed through a blended learning approach, combining distant learning through videos and digital materials with on-site or live LL workshops.

\section{Future Work}

The next steps for this work are to:

- Complete this study with analysis of the qualitative data from the workshop focusing on "Smart buildings \& microgrids"
- Duplicate this method with other universities and in English in order to compare results. This should be possible through partners of the SMAGRINET project.

- Produce and implement the continuous training programs in order to evaluate the results of the methods with industrialists and local policymakers.

In addition to this work, another research perspective emerged as regards LL methods. The approach suggested here is based on the quadruple helix innovation models bringing together the public \& private sector, academics, and civil society. LL methods are known to be suitable for this situation. However, the energy transition challenges arise from ecological concerns associated with the environmental aspect of the quintuple helix innovation model. The environment and natural environment should be considered as part of the innovation process [34]. The systemic vision applied to the educational design process implies keeping the ecological dimension in mind, but does add complexity to the process. The authors are convinced that systemic principles can be combined with LL approaches to respond more effectively to the actual challenges that are related to ecological aspects most of the time. One avenue to be explored is the personification of the environment during the living lab workshop in order to ensure consideration of the exchanges between the resource people.

\section{ACKNOWLEDGMENTS}

This project has received funding from the European Union's Horizon 2020 research and innovation program under grant agreement no. 837626. The authors thank: ENSGSI students and teachers from the IUVTT, EDUTER and INGEXYS courses (2019-2020); experts from the LUE ULHys project.

\section{REFERENCES}

[1] National Energy Technology Laboratory, "A Systems view of the modern," 2007.

[2] European Commission, "2020 climate \& energy package," European Commission website. [Online]. Available: https://ec.europa.eu/clima/policies/strategies/2020_en. [Accessed: 21May-2020].

[3] European Commission, "2030 climate \& energy framework," European Commission website. [Online]. Available: https://ec.europa.eu/clima/policies/strategies/2030_en\#tab-0-0.

[4] European Commission, "2050 long-term strategy," European Commission website. [Online]. Available: https://ec.europa.eu/clima/policies/strategies/2050_en. [Accessed: 21May-2020].

[5] N. K. Özbolat, K. Haegeman, and K. Sereti, "European Institute of Innovation and Technology (EIT) Knowledge and Innovation Communities (KICs): Collaboration in a RIS3 Context," Publications Office of the European Union, 2019.

[6] L. Dupont, L. Morel, and C. Guidat, "Innovative public-private partnership to support Smart City: the case of "Chaire REVES," J. Strateg. Manag., vol. 8, no. 3, pp. 245-265, Aug. 2015.

[7] M. Pallot, B. Trousse, B. Senach, and D. Scapin, "Living Lab research landscape: from user-centred design and user experience towards user co-creation," in First European Summer School "Living Labs"- 25-27 Août., 2010.

[8] B. Baccarne, S. Logghe, D. Schuurman, and L. De Marez, "Governing Quintuple Helix Innovation: Urban Living Labs and Socio-Ecological Entrepreneurship," Technol. Innov. Manag. Rev., vol. 6, no. 3, pp. 2230, Mar. 2016.

[9] C. Liedtke, M. Jolanta Welfens, H. Rohn, and J. Nordmann, "LIVING LAB: User-driven innovation for sustainability," Int. J. Sustain. High. Educ., vol. 13, no. 2, pp. 106-118, 2012. 
[10] S. S. Hansen, "The Campus as a Living Laboratory: Macalester College Case Study," in Handbook of Theory and Practice of Sustainable Development in Higher Education, vol. 3, W. Leal Filho, L. L. Brandli, P. Castro, and J. Newman, Eds. 2017, pp. 223-239.

[11] K. Al Khuffash, "Smart grids-Overview and background information," in Application of Smart Grid Technologies, Elsevier, 2018, pp. 1-10.

[12] C. W. Gellings and K. E. Parmenter, "Chapter 13 Demand-Side Management," in Energy Management and Conservation Handbook, F. Kreith and D. Y. Goswami, Eds. Taylor \& Francis, 2016, pp. 387-408.

[13] P. Samadi, A.-H. Mohsenian-Rad, R. Schober, V. W. S. Wong, and J. Jatskevich, "Optimal Real-Time Pricing Algorithm Based on Utility Maximization for Smart Grid," in 2010 First IEEE International Conference on Smart Grid Communications, 2010, pp. 415-420.

[14] SETIS, "Smart Electricity Grids: Technology Information Sheet," 2014.

[15] W. Saad, Z. Han, H. Poor, and T. Basar, "Game-Theoretic Methods for the Smart Grid: An Overview of Microgrid Systems, Demand-Side Management, and Smart Grid Communications," IEEE Signal Process. Mag., vol. 29, no. 5, pp. 86-105, Sep. 2012.

[16] European Commission, "European SmartGrids Technology Platform Vision and Strategy for the Electricity Networks of the Future," 2006.

[17] X.-P. Zhang, "Development of European Energy Internet and the role of Energy Union," in The Energy Internet, Elsevier, 2019, pp. 347-367.

[18] L. Tronchin, M. Manfren, and B. Nastasi, "Energy efficiency, demand side management and energy storage technologies - A critical analysis of possible paths of integration in the built environment," Renew. Sustain. Energy Rev., vol. 95, pp. 341-353, Nov. 2018.

[19] J. D. Fonseca, M. Camargo, J.-M. Commenge, L. Falk, and I. D. Gil, "Trends in design of distributed energy systems using hydrogen as energy vector: A systematic literature review," Int. J. Hydrogen Energy, vol. 44, no. 19, pp. 9486-9504, Apr. 2019.

[20] Q. Sun, "Coordinated Power Management Control Strategy for Interconnected AC and DC Microgrids," 2019, pp. 93-127.

[21] C. Dell'Era and P. Landoni, "Living Lab: A Methodology between User-Centred Design and Participatory Design," Creat. Innov. Manag., vol. 23, no. 2, pp. 137-154, Jun. 2014

[22] D. Schuurman, "Bridging the gap between Open and User Innovation? Exploring the value of Living Labs as a means to structure user contribution and manage distributed innovation," Ghent University, Ghent, 2015.

[23] L. Dupont, J. Mastelic, N. Nyffeler, S. Latrille, and É. Seulliet, "Living lab as a support to trust for co-creation of value: application to the consumer energy market,” J. Innov. Econ., vol. 28, no. 1, p. 53, 2019.
[24] European Commission, "Living Labs for regional innovation ecosystems," Smart Specialisation Platform, 10-May-2020. [Online]. Available: https://s3platform.jrc.ec.europa.eu/living-labs. [Accessed: 23-May-2020].

[25] T. C. Reeves, "How do you know they are learning? The importance of alignment in higher education," Int. J. Learn. Technol., vol. 2, no. 4, p. 294, 2006.

[26] E. G. Carayannis and D. F. J. Campbell, Mode 3 Knowledge Production in Quadruple Helix Innovation Systems. New York, NY: Springer New York, 2012.

[27] P. van Waart, I. Mulder, and C. de Bont, "A Participatory Approach for Envisioning a Smart City,” Soc. Sci. Comput. Rev., vol. 34, no. 6, pp. 708-723, Dec. 2016.

[28] L. Dupont, A. Gabriel, M. Camargo, and C. Guidat, "Collaborative innovation projects engaging open communities: A case study on emerging challenges," in 2017 International Conference on Engineering, Technology and Innovation (ICE/ITMC), 2017, pp. 1082-1091.

[29] T. Schwartz et al., "What People Do with Consumption Feedback: A Long-Term Living Lab Study of a Home Energy Management System,” Interact. Comput., vol. 27, no. 6, pp. 551-576, Nov. 2015.

[30] J. Evans, R. Jones, A. Karvonen, L. Millard, and J. Wendler, "Living labs and co-production: University campuses as platforms for sustainability science," Curr. Opin. Environ. Sustain., vol. 16, pp. 1-6, Oct. 2015.

[31] L. Dupont, M. Pallot, and L. Morel, "Exploring the Appropriateness of Different Immersive Environments in the Context of an Innovation Process for Smart Cities.," in 22nd ICE/IEEE International Technology Management Conference, 2016.

[32] L. Dupont, L. Morel, J. Hubert, and C. Guidat, "Study case: Living Lab Mode for urban project design: Emergence of an ad hoc methodology through collaborative innovation," in 2014 International Conference on Engineering, Technology and Innovation (ICE), 2014, pp. 1-9.

[33] L. Dupont, J. Lacroix, and J. Hubert, "Rapport technique final du thème «Performance énergétique global et ville intelligente » à l'usage du Grand Nancy et des acteurs de l'EcoQuartier.," Université de Lorraine, Nancy, France, 2014.

[34] E. G. Carayannis and R. Rakhmatullin, "The Quadruple/Quintuple Innovation Helixes and Smart Specialisation Strategies for Sustainable and Inclusive Growth in Europe and Beyond," J. Knowl. Econ., vol. 5, no. 2, pp. 212-239, Jun. 2014. 